\title{
THE USE OF ACTION RESEARCH IN DIAGNOSING AND IMPROVING COOPERATION BETWEEN AN ENTERPRISE AND ITS SUPPLIERS
}

\author{
Monika Jedynak
}

\begin{abstract}
Background. One of the key success factors in the activities of the modern organization is working with suppliers. In some cases, the content of this cooperation is codified in the form of formalized procedures. This is when the organization introduces a standardised quality management system in compliance with ISO 9001. Diagnosis and improvement of cooperation with the suppliers in this kind of organizations can be based on a methodological approach known as action research. In the article an attempt of illustration the possible use of action research as an approach to science on the one hand and on the other - practical solutions supplier relationship management problems.
\end{abstract}

Research aims. The objective of this article is to present possibilities of using action research as a research approach useful in diagnosing and designing a path of cooperation between a business enterprise and its suppliers.

Methodology. The article is based on a review of the carefully selected literature on the genesis, essence, and characteristic features of action research. Additionally, it includes an exemplification of the specific use of the action research process and techniques in diagnosing as well as a proposed procedure for improving cooperation with suppliers in a business enterprise representing the heat generation sector.

Key findings. The research results include the following: presenting the genesis of action research, identifying the ways of defining action research, mapping the most important features of this approach, as well as showing its usefulness in solving a particular business management problem arising out of cooperation with suppliers within the context of the binding requirements specified in the standard ISO 9001:2015. The results of the literature research are of a universal character. Because the empirical research was conducted in just one enterprise representing a specific industry sector, its results cannot be generalized uncritically. Simultaneously, it should be noted that the methodological approach used in the research

Jagiellonian University. E-mail: monika.jedynak@uj.edu.pl 
as well as the organizational and technical tools can be a source of inspiration for research concerning other problems and organizations.

Keywords: action research, cooperation, management, suppliers.

\section{INTRODUCTION}

The multiplicity, variety and significance of research problems characteristic of the management sciences justify continuous care about the methodology of research in this branch of science. The authors exploring the sphere of research methodologies (e.g. Czakon, 2016) often emphasize that a considerable, or maybe even dominant, part of research problems studied by the management sciences do not succumb to the laws of statistics and it is difficult to apply quantitative methods and techniques to such problems. The qualitative approach appears to be more useful as it is sensitive and open to various differences, contexts and flavours characteristic of examined organizations, issues or processes.

Such a convention of conducting research in the management sciences is perfectly compatible with the approach of action research, which is the focus of the author's interest.

The article consists of two major parts. The review part contains an analysis of the relevant literature aimed at achieving cognitive effects connected with presenting the genesis of action research, identifying the ways of defining this approach, and mapping its most important qualities. The empirical part includes an exemplification of the use of action research with respect to the problem of cooperation between an enterprise and its suppliers within the context of compliance with the requirements of the standard ISO 9001:2015.

\section{AN OUTLINE OF THE GENESIS OF ACTION RESEARCH}

We owe the introduction of the term "action research" to the famous researcher Kurt Lewin, known as "the father of social psychology". In the 1940s, when Lewin was popularizing action research, the dominant role was still being played by the paradigm characteristic of the principles of scientific management formulated by Frederick Winslow Taylor (Skinner, 2017). Lewin's thoughts were moving towards an approach to 
organizational and group behaviours which constituted an alternative to what Taylor had proposed earlier; he also focused on work conditions, which, according to him, should be more decent for all members of an organization (Lewin, 1946). Proposed by Lewin and contrasting with scientific management, the canons of action research were based, among other things, on participation understood generally on the one side, but very concretely on the other side, because, for example, Lewin assumed that project participants would share in project results, i.e. generated knowledge. In his concepts, he emphasized the synergy of practical experience with quasi experimental scientific methods. Simplifying to a considerable degree, it can be said that Lewin's philosophy is expressed in the following sentence: "no action without research and no research without action" (Adelman, 1993, p. 8). Although some of Lewin's ideas behind the use of action research were first outlined in the mid-1930s, his first paper based on the action research paradigm was published in 1946 and focused on the way minority ethnic groups could raise their levels of self-esteem, and achieve higher levels of independence and equality (Skinner, 2017, p. 13).

Carr (2006), who attempts to present the genesis of action research holistically, is of the opinion that the conventional methods of illustrating the history of this approach consist in distinguishing its two basic phases: the first comprising the period between the 1920s and the $1950 \mathrm{~s}$, and the other - the subsequent years. In the former period Lewin's pioneering works were crowned particularly with methodological models of conduct within the scope of action research consisting of the following three recommended stages: planning, acting, and searching for data on achieved effects. At that time action research acquired the status of a method which made it possible to introduce theories coming from social sciences into the practice of management and to test such theories by assessing their practical effectiveness (Carr, 2006).

On the other hand, the latter period can be characterized by the following major developmental tendencies related to action research (Carr, 2006; MacDonald, 2012; Thiollent, 2011):

- the diffusion of the method and its numerous applications in some sectors and geographical areas (e.g. its intensive use in solving educational problems in the UK in the early 1970s);

- the development of models of conduct and detailed techniques connected with the application of the method resulting in the isolation of its various versions as well as related methods; 
- the growth of interest in the application of the method among researchers representing such research disciplines and orientations as sociology, anthropology, social psychology, philosophy, feminist research, management and community-based research.

Undertaking a description of the essence of action research, Greenwood (2002), the renowned researcher specializing in this method, claims that its permanent and timeless quality is a dialogue between theory and practice. Such a dialogue appears to be the basic source of the method's continuing popularity and unflagging vitality.

Meanwhile, in his genetic review of the literature dedicated to explaining the nature of action research, Tripp (2005) emphasizes that the genesis of the method is crowned with the co-occurrence of four important and apparently separate processes, i.e. the diagnostic, participatory, empirical and experimental processes.

\section{DEFINING ACTION RESEARCH}

Tripp (2005) elaborates on difficulties accompanying the attempts to define action research. He identifies the following two sources of such difficulties: first, it is such a natural process that it comes in many different guises, and second, it has been developed differently for different applications. A confirmation of the foregoing concerns can be seen in the proposed definitions of action research included in Table 1.

An analysis of the proposed definitions included in Table 1 indicates a considerable diversity of expressions used to define action research. On the other hand, the common characteristic of the presented definitions is their contextual character, i.e. they illustrated contexts in which action research gets involved. Wittmayer et al. (2013) draw attention to the key role of the first word in the name "action research". According to them, the term "action" in action research refers to the real-world change the researchers and the participants aim for. Analysing the definitions of action research, Surdyk (2006) considers their hidden critical dimension as the most important element. According to him, such a critical dimension suggests going beyond researching the closest actions in a given area and undertaking a critical analysis of such actions. 
Table 1. Selected proposed definitions of action research

\begin{tabular}{|l|l|}
\hline Author & Definition \\
\hline $\begin{array}{l}\text { Greenwood \& Lewin, } \\
2007\end{array}$ & $\begin{array}{l}\text { A way of working in the field of utilizing multiple research tech- } \\
\text { niques aimed at enhancing change and generating data for scien- } \\
\text { tific knowledge production. Action research rests on processes of } \\
\text { collaborative knowledge development and action design involving } \\
\text { local stakeholders as full partners in mutual learning processes. }\end{array}$ \\
\hline $\begin{array}{l}\text { Bradbury \& Reason, } \\
2003\end{array}$ & $\begin{array}{l}\text { An approach blurring the traditional division between objectivity } \\
\text { and subjectivity and seeking to empower research subjects to } \\
\text { influence decision making for their own aspirations. }\end{array}$ \\
\hline $\begin{array}{l}\text { Wittmayer et al., } \\
2013\end{array}$ & $\begin{array}{l}\text { A broad field spanning approaches to collaborative research } \\
\text { from different traditions, such as political economy, pragmatic } \\
\text { philosophy, community development, education, participatory } \\
\text { rural development. }\end{array}$ \\
\hline Surdyk, 2006 & $\begin{array}{l}\text { A form of research based on self-enquiry undertaken by partici- } \\
\text { pants of a social situation in order to strengthen the rationality } \\
\text { and justification of their actions as well as to improve the } \\
\text { understanding of such actions and a situation in which they are } \\
\text { performed. }\end{array}$ \\
\hline
\end{tabular}

Source: the author's own work.

\section{FEATURES OF ACTION RESEARCH}

The next stage in the discussion of the essence of action research is an attempt to present a more detailed characteristic of its features.

The features collected in Table 2 show a polymorphic and complex character of action research. Participation is mentioned the most often as its characteristic feature. The other features emphasize work mechanisms used in this approach as well as acquired effects. Meanwhile, discussing the qualities of action research, Thiollent (2011) assets that, due to their number and specific separateness, these features determine the alternative character and methodological identity of action research based partly on its opposition to the other methodological approaches.

Some authors focus in their discussions on the strengths of action research. For example, MacDonald (2012) notes that action research is strongly value oriented, seeking to address issues of significance concerning the flourishing of human persons, their communities, and the wider ecology in which they participate. According to Maguire (1987), in action research, collective inquiry builds ownership of information, and therefore, the research process becomes demystified, creating space for trust to be developed. 
Table 2. Major features of action research

\begin{tabular}{|c|c|c|c|c|c|c|}
\hline \multirow[b]{2}{*}{ Specification } & \multicolumn{6}{|c|}{ Author } \\
\hline & 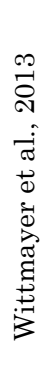 & 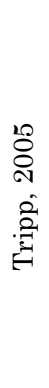 & 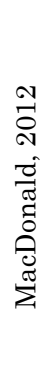 & 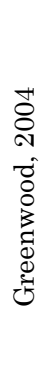 & 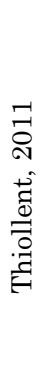 & 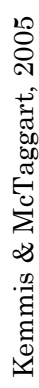 \\
\hline Self-inquiry of the action researcher & $\mathrm{x}$ & & & & & \\
\hline Ethical character & $\mathrm{x}$ & & & & & \\
\hline Various roles of the researcher & $\mathrm{x}$ & & & & & \\
\hline Opening communicative space & $\mathrm{x}$ & & & & & \\
\hline Dealing with communicative spaces & $\mathrm{x}$ & & & & & \\
\hline Dealing with power differences & $\mathrm{x}$ & & & & & \\
\hline Innovative & & $\mathrm{x}$ & & & & \\
\hline Continual (rather than occasional) & & $\mathrm{x}$ & & & & \\
\hline Pro-active strategically driven & & $\mathrm{x}$ & & & & \\
\hline Participatory & & $\mathrm{x}$ & $\mathrm{x}$ & & $\mathrm{x}$ & $\mathrm{x}$ \\
\hline Interventionist & & $\mathrm{x}$ & & & & \\
\hline Problematised & & $\mathrm{x}$ & & & & \\
\hline Deliberated & & $\mathrm{x}$ & & & & \\
\hline Documented & & $\mathrm{x}$ & $\mathrm{x}$ & & & \\
\hline Understood & & $\mathrm{x}$ & $\mathrm{x}$ & & & \\
\hline Disseminated & & $\mathrm{x}$ & & & & \\
\hline Qualitative & & & $\mathrm{x}$ & & & \\
\hline Integrating & & & $\mathrm{x}$ & & & \\
\hline Clarifying & & & $\mathrm{x}$ & & & \\
\hline Compromised & & & $\mathrm{x}$ & & & \\
\hline Combined & & & & $\mathrm{x}$ & & \\
\hline Placed between micro- and macro-perspectives & & & & $\mathrm{x}$ & & \\
\hline Complex & & & & $\mathrm{x}$ & & \\
\hline Alternative & & & & & $\mathrm{x}$ & \\
\hline Social & & & & & $\mathrm{x}$ & $\mathrm{x}$ \\
\hline Based on experience & & & & & $\mathrm{x}$ & \\
\hline
\end{tabular}




\begin{tabular}{|l|l|l|l|l|l|c|}
\hline Standardizing & & & & & $\mathrm{x}$ & \\
\hline Oriented towards results & & & & & $\mathrm{x}$ & \\
\hline Practical & & & & & & $\mathrm{x}$ \\
\hline Collaborative & & & & & & $\mathrm{x}$ \\
\hline Emancipatory & & & & & & $\mathrm{x}$ \\
\hline Critical & & & & & & $\mathrm{x}$ \\
\hline Reflexive & & & & & & $\mathrm{x}$ \\
\hline Transforming & & & & & $\mathrm{x}$ \\
\hline
\end{tabular}

Source: the author's own work.

Furthermore, challenges accompanying the use of action research are referred to in the following opinions expressed by scholars specializing in this method:

- There is generally lack of access to a sufficiently comprehensive and balanced way to learn about the diverse origins, theories, methods, motives, and problems associated with this complex field (Greenwood \& Lewin, 2007);

- Action research can also be challenging due to its inclusion of community members in the research team, who may struggle to maintain their commitment to the research project over time (Gillis \& Jackson, 2002);

- There may be a divergence of perspectives, values, and abilities among community members; consensus for determining what social issues require attention and the timeframe anticipated for the change might thus be difficult (McNiff \& Whitehead, 2006).

Analysing the conditions for the use of action research, Skinner (2017) and Thiollent (2011) draw attention to the significant role of ethical aspects. Among the qualities of the ethical use of action research, Brydon-Miller (2012) lists the following: autonomy, sovereignty, beneficence, justice, caring, respect, commitment, transparency and democratic practice.

The approach of action research includes a considerable number of particular techniques, for example focus groups, participant observation, interviews.

There are also differences concerning sequences of steps followed in the process of using action research. A few selected approaches in this respect are presented in Table 3. 
Table 3. Selected approaches to the action research process

\begin{tabular}{|l|l|}
\hline Author & Recommended sequence of actions \\
\hline \multirow{5}{*}{ Wittmayer et al. (2013) } & 1. Pre-preparation \\
& 2. Preparation and exploration \\
& 4. Backcasting, pathways and agenda building \\
& 5. Experimenting and implementing \\
& 6. Monitoring and evaluation \\
\hline \multirow{3}{*}{ Tripp (2005) } & 1. Planning \\
& 2. Implementation \\
& 3. Evaluation \\
\hline \multirow{5}{*}{ Skinner (2017) } & 1. Discussion \\
& 2. Decision \\
& 3. Action \\
& 4. Evaluation \\
& 5. Revision \\
\hline
\end{tabular}

Source: the author's own work.

They differ in the number of proposed steps and thus also in the degree of aggregation/detail represented by such steps. However, in all proposed approaches, the sequence of steps refers to the classical approaches to the process of management.

The long period of the development of action research resulted in the occurrence of many variants of the method. For example, Kemmis \& McTaggart (2005) introduce the notion of a family of action research which comprises the following: participatory research, critical action research, classroom action research, action learning, action science, soft system approaches as well as industrial action research. On the basis of his review of the literature on the subject, Skinner (2017) distinguishes the following three types of action research;

- Type 1, including the following aspects: technical, technical collaborative, scientific-technical.

- Type 2, including the following aspects: practical, mutual collaborative, practical-deliberative.

- Type 3, including the following aspects: emancipatory, enhancement, critical emancipatory.

The foregoing proposals overlap only in part. The former focuses more on the types of action research based on various applications of the approach, while the latter emphasizes the methodological context of actions. 


\section{RESEARCH METHODOLOGY}

The empirical research was conducted in a public utility enterprise located in the south of Poland, whose business activities were the generation and distribution of heat and hot water. Carried out in 2017, the research had the form of a consultancy project in which the author fulfilled the role of an external organizational consultant. In the agreement with representatives of the organization, it was decided that the project would be carried out with the use of the action research approach.

The subject matter of the research was the enterprise's solutions concerning its cooperation with suppliers. The reason for initiating the project was changes introduced in the standard ISO 9001 in 2015. Because the organization maintained an integrated management system based on the aforementioned standard, changes in its requirements constituted a natural reason for performing an analysis of the organization's compliance with the new requirements and subsequently for designing and implementing adjustments, if any, in the management system.

Table 4 presents the major components of the applied research methodology.

Table 4. A presentation of the major components of the research methodology

\begin{tabular}{|c|c|}
\hline $\begin{array}{l}\text { Subject matter } \\
\text { of research }\end{array}$ & $\begin{array}{l}\text { Formalized solutions concerning cooperation with suppliers in the } \\
\text { enterprise under examination }\end{array}$ \\
\hline $\begin{array}{l}\text { Research } \\
\text { objectives }\end{array}$ & $\begin{array}{l}\text { 1. Identifying potential gaps in the existing solutions concerning } \\
\text { cooperation with suppliers with respect to the requirements of the } \\
\text { standard ISO 9001:2015 } \\
\text { 2. Developing a procedure adjusting the integrated management sys- } \\
\text { tem to the requirements of the standard ISO 9001:2015 with respect } \\
\text { to cooperation with suppliers }\end{array}$ \\
\hline $\begin{array}{l}\text { Research } \\
\text { participants }\end{array}$ & $\begin{array}{l}\text { 1. The author } \\
\text { 2. The Management Board Representative for Management Systems } \\
\text { 3. Logistics Department Manager } \\
\text { 4. Logistics Department Specialists } \\
\text { 5. Managers of selected organizational units (internal customers of the } \\
\text { Logistics Department) } \\
\text { 6. Legal Department Manager }\end{array}$ \\
\hline $\begin{array}{l}\text { Applied } \\
\text { research } \\
\text { techniques }\end{array}$ & $\begin{array}{l}\text { 1. An analysis of the content of information documented in the inte- } \\
\text { grated management system } \\
\text { 2. The checklist technique } \\
\text { 3. The focus group interview technique } \\
\text { 4. Participating observation }\end{array}$ \\
\hline
\end{tabular}

Source: the author's own work. 
The research was performed based on the sequence of steps typical of action research, initiated by identifying stakeholders and preparing a research schedule. Subsequently during a period of three months the research was carried out with the use of the techniques specified in Table 4. The character of the research was partly diagnostic, and partly oriented towards design development.

\section{RESULTS}

The fundamental measurable effect of the first stage of the conducted research was diagnostic findings concerning the degree to which the solutions in place in the enterprise and formalized in the integrated management system fulfil the requirements applicable to cooperation with suppliers.

Table 5. The results of the analysis of gaps in the integrated management system with respect to the requirements of the standard ISO 9001:2015

\begin{tabular}{|c|c|}
\hline Diagnostic questions & Research results \\
\hline $\begin{array}{l}\text { Were suppliers taken into consider- } \\
\text { ation as one of the external factors } \\
\text { important for the strategic goals and } \\
\text { directions in the enterprise's develop- } \\
\text { ment? }\end{array}$ & $\begin{array}{l}\text { Yes, a few groups of suppliers were taken } \\
\text { into consideration. Strategic importance was } \\
\text { assigned to heat and hot water suppliers. } \\
\text { However, no formalized and docu- } \\
\text { mented analysis of the enterprise's busi- } \\
\text { ness context, including its suppliers, } \\
\text { was performed. }\end{array}$ \\
\hline $\begin{array}{l}\text { 2. Does the enterprise monitor and } \\
\text { review information on its suppliers? }\end{array}$ & $\begin{array}{l}\text { Yes, it does. This process occurs in a few } \\
\text { stages. All suppliers have individual elec- } \\
\text { tronic files where both positive and negative } \\
\text { incidents related to cooperation are entered. } \\
\text { Such information, however, does not } \\
\text { constitute the subject matter of analysis } \\
\text { during management reviews. }\end{array}$ \\
\hline $\begin{array}{l}\text { 3. Has the enterprise identified the } \\
\text { requirements of its suppliers as one of } \\
\text { the important groups of stakeholders? } \\
\text { Are such requirements monitored and } \\
\text { reviewed on an ongoing basis? }\end{array}$ & $\begin{array}{l}\text { No, it has not. The enterprise has not carried } \\
\text { out a necessary comprehensive analysis of } \\
\text { its stakeholders. }\end{array}$ \\
\hline $\begin{array}{l}\text { 4. Has the enterprise identified its } \\
\text { suppliers as an external source of } \\
\text { knowledge necessary for the proper } \\
\text { functioning of processes? }\end{array}$ & $\begin{array}{l}\text { No, it has not. Knowledge management } \\
\text { processes have not been codified yet. }\end{array}$ \\
\hline $\begin{array}{l}\text { 5. Are the processes, products and } \\
\text { services provided by the supplier } \\
\text { distinguished within the management } \\
\text { system? }\end{array}$ & $\begin{array}{l}\text { Yes, they are. They are divided with respect } \\
\text { to heat and hot water suppliers, construction } \\
\text { and repair service suppliers, and other } \\
\text { suppliers. }\end{array}$ \\
\hline
\end{tabular}




\begin{tabular}{|c|c|}
\hline $\begin{array}{l}\text { 6. Has the enterprise specified forms } \\
\text { of supervision over the processes, } \\
\text { products and services provided by the } \\
\text { suppliers? }\end{array}$ & $\begin{array}{l}\text { Yes, it has. Such forms of supervision are } \\
\text { included in a few operational procedures. }\end{array}$ \\
\hline $\begin{array}{l}\text { 7. Has the enterprise specified criteria } \\
\text { for the assessment, selection, moni- } \\
\text { toring and reassessment of its suppli- } \\
\text { ers? If so, are such criteria used? }\end{array}$ & $\begin{array}{l}\text { Yes, it has. Yes, they are used. The criteria } \\
\text { are diversified depending on the supplier's } \\
\text { status. }\end{array}$ \\
\hline $\begin{array}{l}\text { 8. Does the enterprise generate and } \\
\text { store documented information con- } \\
\text { cerning supplier assessments? }\end{array}$ & $\begin{array}{l}\text { Yes, it does. Such information concerns the } \\
\text { selection and assessment of suppliers, trans- } \\
\text { actions with suppliers, and complaints. }\end{array}$ \\
\hline $\begin{array}{l}\text { 9. Has the enterprise ensured supervi- } \\
\text { sion over the processes executed by } \\
\text { its suppliers? Have means of such } \\
\text { supervision been specified? }\end{array}$ & $\begin{array}{l}\text { Yes, with respect to the processes of heat } \\
\text { and hot water transmission and distribution } \\
\text { as well as with respect to the construction } \\
\text { and repair processes. In both cases, the } \\
\text { enterprise has specified relevant means of } \\
\text { supervision. }\end{array}$ \\
\hline $\begin{array}{l}\text { 10. Has the enterprise analysed a } \\
\text { potential influence of the processes, } \\
\text { products and services provided by its } \\
\text { suppliers on its ability to meet the } \\
\text { requirements of its customers and } \\
\text { other stakeholders? }\end{array}$ & Such an analysis has not been performed. \\
\hline $\begin{array}{l}\text { 11. Does the enterprise inform its } \\
\text { suppliers about the requirements } \\
\text { concerning the provided processes, } \\
\text { products and services, the ways in } \\
\text { which they are approved as well as } \\
\text { the competences of people employed } \\
\text { by the suppliers and actions related to } \\
\text { the supplier assessment procedure? }\end{array}$ & $\begin{array}{l}\text { Yes, such requirements are communicated } \\
\text { in requests for quotations, terms of reference } \\
\text { and concluded agreements. }\end{array}$ \\
\hline
\end{tabular}

*Notes: 1) The bold type indicates diagnostic findings signalling non-compliance with the requirements of the standard ISO 9001:2015; 2) The audit questions have been formulated based on: Jedynak, 2017, p. 143.

Source: the author's own work.

The conducted research indicated these elements of cooperation with suppliers which, from the perspective of the standard ISO 9001:2015, required obligatory implementation and which had not yet been implemented at the time of the project. The analysis showed that the enterprise had not met the requirements which were new and had not been included in the earlier 2008 version of the standard ISO 9001.

Based on the acquired diagnostic findings, the author in cooperation with the enterprises' representatives designed a procedure for adjusting the integrated management system to the requirements of the standard ISO 9001:2015 (Table 6). 
Table 6. A procedure adjusting the integrated management system to the requirements of the standard ISO 9001:2015 with respect to cooperation with suppliers

\begin{tabular}{|c|c|c|c|c|c|c|c|c|c|c|c|c|c|c|}
\hline \multicolumn{8}{|c|}{ People } & \multirow[b]{2}{*}{ Action } & \multicolumn{6}{|c|}{ Documentation } \\
\hline 旁 & 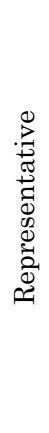 & 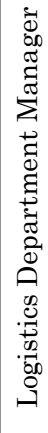 & 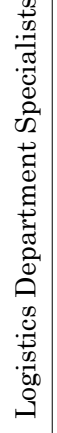 & 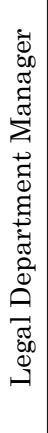 & 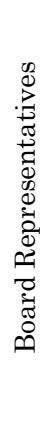 & 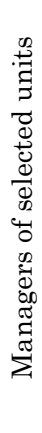 & 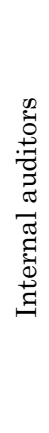 & & 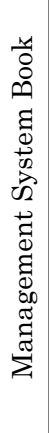 & 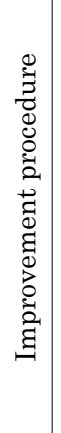 & 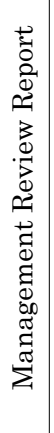 & 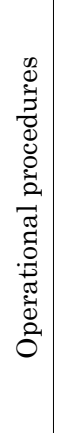 & 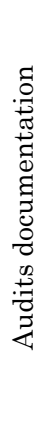 & 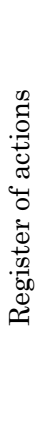 \\
\hline $\mathrm{x}$ & $\mathrm{x}$ & $\mathrm{x}$ & & & $\mathrm{x}$ & $\mathrm{x}$ & & $\begin{array}{l}\text { Conducting an analysis of } \\
\text { suppliers' influence on the } \\
\text { objectives and strategic direc- } \\
\text { tions of the enterprise's devel- } \\
\text { opment (as part of a business } \\
\text { context analysis). }\end{array}$ & $\mathrm{x}$ & & & & & \\
\hline $\mathrm{x}$ & $\mathrm{x}$ & & & & & & & $\begin{array}{l}\text { Broadening the scope of man- } \\
\text { agement reviews with infor- } \\
\text { mation concerning cooperation } \\
\text { with suppliers. }\end{array}$ & & $\mathrm{x}$ & $\mathrm{x}$ & & & \\
\hline $\mathrm{x}$ & $\mathrm{x}$ & $\mathrm{x}$ & $\mathrm{x}$ & $\mathrm{x}$ & & $\mathrm{x}$ & & $\begin{array}{l}\text { Determining suppliers' re- } \\
\text { quirements within the scope of } \\
\text { a comprehensive assessment of } \\
\text { the enterprise's stakeholders }\end{array}$ & $\mathrm{x}$ & & & $\mathrm{x}$ & & \\
\hline $\mathrm{x}$ & $\mathrm{x}$ & $\mathrm{x}$ & $\mathrm{x}$ & $\mathrm{x}$ & & $\mathrm{x}$ & & $\begin{array}{l}\text { Codifying knowledge manage- } \\
\text { ment processes, taking into } \\
\text { account the role of suppliers } \\
\text { as a source of knowledge for } \\
\text { the enterprise. }\end{array}$ & & & & $\mathrm{x}$ & & \\
\hline $\mathrm{x}$ & $\mathrm{x}$ & $\mathrm{x}$ & & & $\mathrm{x}$ & $\mathrm{x}$ & & $\begin{array}{l}\text { Conducting an analysis of a } \\
\text { potential influence of the pro- } \\
\text { cesses, products and services } \\
\text { provided by suppliers on the } \\
\text { enterprise's ability to meet the } \\
\text { requirements of its customers } \\
\text { and other stakeholders. }\end{array}$ & $\mathrm{x}$ & & & & & \\
\hline $\mathrm{x}$ & $\mathrm{x}$ & & & & & & $\mathrm{x}$ & $\begin{array}{l}\text { Conducting internal audits } \\
\text { assessing the fulfilment of the } \\
\text { aforementioned requirements. }\end{array}$ & & & & & $\mathrm{x}$ & \\
\hline $\mathrm{x}$ & $\mathrm{x}$ & $\mathrm{x}$ & $\mathrm{x}$ & $\mathrm{x}$ & & $\mathrm{x}$ & & $\begin{array}{l}\text { Implementing corrective mea- } \\
\text { sures, if any. }\end{array}$ & & & & & & $\mathrm{x}$ \\
\hline
\end{tabular}

Source: the author's own work. 
The procedure presented in Table 6 takes into consideration the participation of the people involved in the project, the use of the existing management system documentation, and the implementation of such measures as internal audits and corrective measures used typically in assessing and improving standardized management systems.

\section{DISCUSSION}

The empirical research was performed based on a convention typical of action research, taking into consideration the specific character of the subject of the research, i.e. the enterprise's cooperation with suppliers taking place within a formal framework determined by the implemented integrated management system. Such circumstances resulted in combining the methodology characteristic of action research with the practice referred to as the Deming cycle, used in standardized management systems and consisting of the four steps (Plan-Do-CheckAct) typical of the life cycle of such systems.

The acquired diagnostic findings confirmed that the enterprise had not satisfied only some of those requirements which had been absolutely new and had been introduced in 2015 as part of the revision of the standard ISO 9001. The other requirements related to the enterprise's cooperation with suppliers were fulfilled because they had been included in the earlier version of the aforementioned standard and had been properly implemented in the management system; the processes of internal (internal audits) and external (certification audits) assessment of the integrated management system conducted in the past appeared to be effective in confirming that such requirements had been met.

Executing the project in the form of action research, the author chose its participants so that they would represent all important areas of the enterprise's activities, which guaranteed a higher level of their involvement in the project and resulted in various points of view being taken into account in the process of diagnosing and improving the management system.

The designed procedure for adjusting the integrated management system to the requirements of the standard ISO 9001:2015 was based on two basic principles. One of them concerned the selection, together with the enterprise's representatives, of a diagnostic approach as a formula for improving the management system. It was based on 
diagnosing the existing solutions and supplementing them with the missing elements. This approach has an evolutionary character.

The other principle was related to preventing the occurrence of the negative effect of suboptimization; this could consist in diagnosing and improving the area of cooperation with suppliers regarded as a separate area without any connections with the other functional areas. Such a risk was reduced by means of the aforementioned selection of the project participants and putting the procedure of adjusting the existing solutions into the broader context of the holistic functioning of the integrated management system. For this reason, some analytical actions related to cooperation with suppliers were designed as a fragment of more comprehensive analyses of the enterprise's business activities.

\section{CONCLUSIONS}

The conducted research allowed the formulation of the following conclusions:

- Action research constitutes a scientific approach particularly useful for solving practical management problems. This is probably why it enjoys continuing popularity manifesting itself in the increasing number of its applications.

- The strictly methodological layer of action research is made up of numerous and diverse proposals for how to approach research procedure processes and principles of conduct. Following the principle of methodological pluralism, it should be stated that between such proposals there occur complementary relationships. Their number and variety allow a more flexible selection adjusted to a particular application and constitute a good basis for developing new framework models of conduct aspiring to become benchmarks.

- As a methodological approach, action research turns out to be useful in diagnosing and solving management problems occurring within standardized management systems based on the requirements of such standards as ISO 9001. If action research is used for such purposes, the applied research approach needs to take into consideration the specific character of the functioning of these management systems, including in particular their formal and personal dimensions. 


\section{REFERENCES}

Adelman, C. (1993). Kurt Lewin and the origins of action research. Educational Action Research, 1(1), 7-24.

Bradbury, H. \& Reason, P. (2003). Action research: An opportunity for revitalizing research purpose and practices. Qualitative Social Work, 2(2), 155-175.

Brydon-Miller, M. (2012). Addressing ethical challenges of community-based research. Teaching Ethics, 12(2), 157-162.

Carr, W. (2006). Philosophy, methodology and action research. Journal of Philosophy of Education, 40(4), 421-435.

Czakon, W. (ed.) (2016). Podstawy metodologii badań w naukach o zarzadzaniu ( $3^{\text {rd }}$ edition). Warszawa: Wydawnictwo Nieoczywiste.

Gillis, A. \& Jackson, W. (2002). Research Methods for Nurses: Methods and Interpretation. Philadelphia: F.A. Davis Company.

Greenwood, D.J. (2002). Action research: Unfulfilled promises and unmet challenges. Concepts and Transformation, 7(2), 117-139.

Greenwood, D.J. (2004). Action research: Collegial responses fulfilled. Concepts and Transformation, 9(1), 85-92.

Greenwood, D.J. \& Lewin, M. (2007). Introduction to Action Research: Social Research for Social Change ( $2^{\text {nd }}$ edition). Tousand Oaks: Sage Publications.

Jedynak, M. (2017). Dostosowanie systemu zarządzania jakością do wymagań standardu ISO 9001:2015 - perspektywa współpracy z dostawcami. In: E. Skrzypek (ed.), Nowa jakość zarzqdzania (pp. 135-143). Lublin: Katedra Zarządzania Jakością i Wiedzą UMCS.

Kemmis, S. \& McTaggart, R. (2005). Participatory action research: Communicative action and the public sphere. In: N.K. Denzin \& Y.S. Lincoln (eds.), The Sage Handbook of Qualitative Research (pp. 559-603). Thousand Oaks: Sage Publications.

Lewin, K. (1946). Action research and minority problems. Journal of Social Issues, 2(4), 34-46.

MacDonald, C. (2012). Understanding participatory action research: A qualitative research methodology option. Canadian Journal of Action Research, 13(2), 34-50.

Maguire, P. (1987). Doing Participatory Action Research: A Feminist Approach. Massachusetts: University of Massachusetts Press.

McNiff, J. \& Whitehead, J. (2006). All You Need to Know About Action Research. Thousand Oaks, Sage Publications.

Skinner, H. (2017). Action Research. In: K. Kubacki \& S. Rundle-Thiele (eds.), Formative Research in Social Marketing (pp. 11-31). Singapore: Springer. 
Surdyk, A. (2006). Metodologia action research i techniki komunikacyjne w glottodydaktyce. In: I. Kamińska-Szmaj, T. Piekot \& M. Zaśko-Zielińska (eds.), Oblicza komunikacji 1: Perspektywy badań nad tekstem, dyskursem i komunikacja (pp. 912-923). Kraków: Krakowskie Towarzystwo Popularyzowania Wiedzy o Komunikacji Językowej Tertium.

Thiollent, M. (2011). Action research and participatory research: An overview. International Journal of Action Research, 7(2), 160-174.

Tripp, D. (2005, 19.01.2018). Action research: A methodological introduction. Retrieved from: http://www.scielo.br/pdf/ep/v31n3/en_a09v31n3.pdf (access: 19.01.2018).

Wittmayer, J., Schapke, N., Feiner, G., Piotrowski, R., van Steenbergen, F. \& Baasch, S. (2013). Action Research for Sustainability: Reflections on transition management in practice. InContext, http://www.incontext-fp7.eu/sites/ default/files/InContext-ResearchBrief-Action_research_for_sustainability. pdf (access: 19.01.2018). 


\section{WYKORZYSTANIE ACTION RESEARCH W DIAGNOZOWANIU I DOSKONALENIU WSPÓKPRACY PRZEDSIĘBIORSTWA Z DOSTAWCAMI}

Tło badań. Jednym z kluczowych czynników sukcesu w działalności współczesnych organizacji jest współpraca $\mathrm{z}$ dostawcami. W niektórych przypadkach treść tej współpracy jest skodyfikowana w postaci sformalizowanych procedur. Tak dzieje się wówczas, kiedy organizacja wprowadza znormalizowany system zarządzania jakościa zgodny z ISO 9001. Diagnoza i doskonalenie współpracy z dostawcami w tego rodzaju organizacjach może się opierać na podejściu metodologicznym nazywanym action research. W artykule podejmuje się próbę ilustracji możliwości wykorzystania action research jako podejścia predysponowanego do z jednej strony naukowego, a z drugiej - praktycznego rozwiązania problemów zarządzania relacjami z dostawcami.

Cel badań. Celem artykułu jest ukazanie możliwości wykorzystania action research jako podejścia badawczego, przydatnego w diagnozie i projektowaniu ścieżki doskonalenia współpracy przedsiębiorstwa z dostawcami.

Metodologia. W artykule wykorzystano przegląd selektywnie dobranej literatury dotyczacej genezy, istoty oraz cech wyróżniających action research. Ponadto uwzględniono egzemplifikację zastosowania procesu i technik action research do specyficznego zastosowania, jakim jest przeprowadzenie diagnozy i sformułowanie propozycji procedury doskonalenia współpracy z dostawcami w przedsiębiorstwie reprezentujących sektor ciepłowniczy.

Kluczowe wnioski. Do rezultatów badań należą: ukazanie genezy action reserach, identyfikacja sposobów jego definiowania, odwzorowanie najważniejszych cech tego podejścia badawczego, a także wykazanie jego przydatności w rozwiązaniu specyficznego problemu zarządzania przedsiębiorstwem, jakim jest współpraca $\mathrm{z}$ dostawcami zachodzaca $\mathrm{w}$ warunkach istnienia wymagań określonych norma ISO 9001:2015. Wyniki badań literaturowych mają charakter uniwersalny. Wyniki badań empirycznych, ze względu na ich prowadzenie w jednym przedsiębiorstwie reprezentujacym specyficzny sektor, nie mogą być bezkrytycznie uogólniane. Równocześnie należy stwierdzić, że zastosowane w tych badaniach podejście metodologiczne oraz narzędzia organizacyjno-techniczne moga być inspiracją w badaniach innych problemów i organizacji.

Słowa kluczowe: action research, współpraca, zarządzanie, dostawcy. 